\title{
Modal Sosial Pembangunan SDM Masyarakat Bali
}

\author{
I Gusti Ayu Wimba \\ Fakultas Ekonomi Bisnis dan Pariwisata \\ Universitas Hindu Indonesia \\ email: igawimba179@gmail.com
}

\begin{abstract}
During this time, the government and the community in implementing development, explicitly only prioritize economic capital and human capital in an individual perspective only. Not many people have highlighted the role of social capital, which is a necessity, in maintaining the results of development that have been carried out. Mainly, Balinese social capital which is hierarchically shaped through values that are invested from an early age, will grow into an accumulation of social capital which will later contribute positively in maintaining a conducive atmosphere in developing human resources for the Balinese people.
\end{abstract}

Keywords: social capital, development, human resources, Balinese people.

\section{PENDAHULUAN.}

Hampir pada setiap periodisasi perekonomian Indonesia, kita selalu berkutat dengan segala bentuk perencanaan pembangunan yaitu strategi pembangunan dan implementasinya, untuk mencapai masyarakat adil dan makmur selalu saja mendapat hambatan. Artinya, pencapaian tujuan pembangunan, yaitu masyarakat Indonesia seutuhnya yang makmur dan berkeadilan belum pernah terwujud secara sempurna. Yang sering disebut sebagai penyebab adalah, kondisi geografis Indonesia yang sangat luas, sehingga masyarakat belum dapat menikmati hasil pembangunan secara adil dan merata. Untuk melaksanakan pembangunan, diperlukan akumulasi modal dalam wujud modal uang dan asset padat lainnya yang harus diinvestasikan oleh pemerintah untuk mencapai tujuan pembangunan. Dalam hal ini, modal uang dan sejumlah asset lainnya di sebut sebagai economic capital. Untuk dapat mengalokasikan sumber daya ekonomi secara efisien, seperti dalam membuat perencanaan, menganalisis rasio-rasio alokasi dana, Prediksi-predikdi prosfektif atas modal yang diinvestasikan dan untuk mengevaluasi hasil pembangunan, diperlukan sumber daya manusia yang kualitasnya representatif untuk mengemban tugas ini. Kualitas sumber daya manusia secara individual disebut sebagai human capital, yang sejatinya juga memerlukan investasi yang tidak kecil. Untuk dua jenis modal ini (economic capital dan human capital) pemerintah Indonesia sudah dengan sangat efisiendan efektif mengalokasikannya untuk mewujudkan tujuan pembangunan. Dan ketersediaanya sudah memadai bahkan berlebih. Tetapi, untuk memelihara hasil pembangunan, yang direncanakan dan dilaksanakan bertahun-tahun, agaknya memerlukan satu jenis modal lagi yaitu modal sosial (social capital). Perhatian secara mendalam pemerintah dan masyarakat kepada modal sosial dan peranannya dalam pembangunan, agaknya belum mendapat proyeksi secara.proporsional.

Fakta empiric menunjukkan, bahwa hasil pembangunan di Provinsi Bali, selalu lebih cantik dari kondisi pembangunan untuk tingkat nasional. Indikator-indikator kinerja pembangunan Bali seperti pertumbuhan ekonomi, tingkat Inflasi, rasio gini, 
kelompok. Dalam hal ini, modal sosial diakui hanya akan eksis apa bila diperngunakan dalam interaksi kelompok masyarakat.

Hasbullah (2006), unsur pokok modal sosial itu terdiri dari enam dimensi yaitu: 1) Partisipasi dalam suatu jaringan, artinya modal sosial tidak dibangun oleh satu individu, melainkan akan terletak padakecenderungan yang tumbuh dalam suatu kelompok untuk bersosialisasi sebagai nilai yang sangat penting. 2) resiprosity, dalam hal ini modal sosial senantiaa diwarnai oleh kecendrungan untuk saling bertukar kebaikan antar individu dalam suatu kelompok atau antar kelompok. 3) Trust adalah rasa percaya dan mempercayai, atau suatu keinginan untuk mengambil resiko dalam hubungan sosial yang didasari oleh perasaan yakin bahwa orang lain akan melakukan sesuatu seperti yang diharapkan atau paling tidak yang lain tidak akan bertindak yang merugikan diri dan kelompoknya. 4) Norma Sosial sesuatu yang terbentuk akibat adanya Trust dalam suatu kepompok yang akan sangat berperan dalam mengontrol bentuk-bentuk perilaku yang tumbuh dan diharapkan oleh masyarakat. 5) Nilai-nilai adalah suatu ide yang sudah turun temurun diakui dan dianggap benar dan penting oleh sekelompok masyarakat. 6) tindakan yang proaktif adalah keinginan yang kuat dari anggota kelompok untuk tidak saja berpartisipasi, tetapi senantiasa berinisiatif mendahului untuk menemukan tindakan bagi keterlibatan mereka dalam suatu kegiatan kelompok masyarakat.

\section{Modal Sosial Masyarakat Bali}

Proses terbentuknya modal sosial bagi masyarakat Bali, sedikit berbeda dengan apa yang dikemukakan oleh para pakar tentang modal sosial. Untuk masyarakat Bali, secara natural dan hirarkis, unsur-unsur modal sosial yang dimiliki oleh masyarakat Bali adalah: 1) nilai-nilai, 2) norma social, 3) trust, 4) resiprocity, 5) partisipasi dalam jaringan, dan 6) tindakan yang proaktif. Satu per satu pembahasan atas dimensi modal sosial ini adalah sebagai berikut:

Nilai-nilai yang dipakai sebagai anutan yang menuntun tingkah laku masyarakat Bali adalah srada. Salah satu srada yang paling mempengaruhi periklu masyarakat Bali pada umumnya, adalah Karma Pala, yaitu percaya pada adanya hasil perbuatan. Secara umum, masyarakat Bali meyakini bahwa apa yang ditanam, pasti itulah yang dipetik. Atau dengan cara yang paling mudah mengatakannya perbuatan baik pasti akan menghasilkan kebaikan, begitu juga sebaliknya perbuatan buruk pasti akan membuahkan hasil yang buruk juga. Begitulah konsep nilai-nilai hasil perbuatan ditanamkan sejak kecil, yang mengakibatkan sejak usia dini sudah timbul keinginan untuk berbuat yang menyenangkan orang lain. Kebiasaan memperlakukan dengan baik orang lain dalam suatu kelompok, akan menyebabkan terbentuknya semacam norma sosial, yang diakui dan dipatuhi bersama dalam suatu kelompok masyarakat.Demikian juga pada masyarakat Bali.

Norma Sosial akan sangat berperan dalam mengontrol bentuk-bentuk perilaku yang tumbuh dalam masyarakat, yang dalam hal ini adalah masyarakat Bali. Norma sosial adalah sekumpulan aturan yang diharapkan dapat dipatuhi dan diikuti oleh anggota masyarakat sebagai suatu entias sosial. Salah satu norma sosial yang diakui dan dipatuhi oleh masyarakat Bali, seperti "gilik-saguluk sabayan taka", yang diimplementasikan dalam sistem kekerabatan pada satu keluarga besar, satu Banjar Adat dan akhirnya pada satu Desa Pekraman. Konfigurasi norma sosial yang tumbuh di tengah masyarakat Bali juga akan menentukan apakah norma-norma tersebut akan memperkuat kerekatan hubungan antar individu dalam kelompok masyarakat Bali dan akan memberikan dampak positif bagi perkembangan masyarakat. Implementasi norma sosial yang kental dalam masyarakat akan membentuk trust yaitu perilaku saling percaya-mempercayai dalam suatu entitas masyarakat, dalam hal ini masyarakat Bali.

Trust adalah sikap saling mempercayai di masyarakat, yang memungkinkan masyarakat tersebut saling bersatu dengan yang lain dalam suatu interaksi sosial. Berbagai tindakan kolektif yang didasari atas rasa saling percaya yang mendalam akan meningkatkan partisipasi 
masyarakat dalam berbagai ragam bentuk dan dimensi, terutama dalam konteks membangun kemajuan bersama. Masyarakat yang kurang memiliki rasa saling mempercayai akan suit menghindari berbagai kerawanan sosial dan ekonomi yang mengancam. Kahancuran rasa saling percaya di masyarakat akan membuat masyarakat cenderung apatis dan hanya menunggu apa yang akan diberikan pemerintah. Kadar trust masyarakat Bali sangat tinggi.baik kepada sesama warga masyarakat, di keluarga besar, di Banjar, di Desa Pekraman, kepada pemerintah Kabupaten/Kota, Pemerintah Privinsi maupun pemerintah Pusat, sehingga sukup resiten untuk mendapat hasutan dari pihak-pihak yang tidak bertanggungjawab untuk turut berdemonstrasi apa lagi hal-hal yang menyangkut perilaku makar lainnya. Tingkat trust sesama masyarakat Bali relatif tinggi, sehingga di Bali cukup aman dari tindak kerawanan sosial dan ekonomi. Tingkat trust yang tinggi dari suatu masyarakat, akan menumbuhkan perilaku "resiprosity" yang tinnggi pula sebagai modal sosial suatu masyarakat.

Resiprosity adalah kecenderungan untuk saling bertukar kebaikan antar individu dalam suatu kelompok. Pola ini bukan sesuatu yang resiprokal seketika, tetapi adalam kombinasi jangka pendek dan jangka panjang dalam nuansa hidup yang altruis yang bersemangat untuk saling mambantu dan mementingkan kepentingan orang lain. Masyarakat yang memiliki bobot resiprositas yang kuat akan melahirkan kelompok masyarakat yang memiliki modal sosial yang tinggi. Kadar resiprosity masyarakat Bali, terlihat jelas pada saat ada upacara kematian pada Banjar adatnya. Masing-masing individu seakan ingin memberi yang terbaik pada aktivitas keagamaan banjar adatnya. Ada semacam rasa takut ditinggalkan oleh sesama dalam kelompok banjarnya. Istilah pada masyarakat Bali "Takut Kesepekang Banjar". Rasa inilah yang membentuk resiprositas masyarakat Bali, dan akhirnya menumbuhkan jiwa bersemangat untuk berpartisipasi dalam jaringan kekerabatan sesama anggota masyarakat.

Partisipasi dalam jaringan, menjustifikasi bahwa modal sosial tidak dibangun oleh satu ndividu, melainkan terletak pada kecenderungan yang tumbuh dalam kelompok untuk bersosialisasi sebagai bagian yang penting sebagai nilai yang mendasar. Pada masyarakat, secara tradisional sudah terbentuk atas dasar kesamaan garis keturunan, pengalamanpengalaman social yang turun-temurun, dan kepercayaan pada dimesnsi religius yang mengakibatkan kecenderungan memiliki tingkat kohesifitas yang tinggi. Pada tataran ini, ditengarai kelompok masyarakat akan cenderung caupinistis, yang dapat saja menjadi kurang kondusif bagi eksistensi kelompok masyarakat lain. Dalam hal ini, masyarakat Bali diakui mempunyai tingkat partisipasi yang tinggi dan mempunyai kesanggupan yang ditinggi untuk beradaptasi dengan budaya-budaya yang datang dari luar Bali, dan sanggup berakselerasi dengan sempurna, tanpa harus meninggalkan identitas budayanya sendiri. Di sini diakui tingkat partisipasi yang tinggi dari suatu kelompok masyarakat akan menunbuhkan tintakan pro-aktif yang sangat positif bagi kelangsungan hidup masyarakat Bali sendiri.

Tindakan yang pro-aktif adalah modal sosial dalam bentuk keinginan yang kuat dari anggota kelompok untuk tidak saja berpartisipasi, tetapi justru senantiasa mencari jalan bagi keterlibatan mereka dalam suatu kegiatan masyarakat. Identitas yang menandai kelompok masyarakat ini adalah mereka cenderung tidak menyukai bantuan yang sifatnya dilayani, tetapi mengharapkan diberikan pilihan untuk lebih banyak melayani secara proaktif. Pada masyarakat Bali, modal sosial ini terlihat pada kesediaan masyarakat untuk memelihara dan menjaga kebersihan lingkungan, terutama pada fasilitas-fasilitas puklik, seperti Balai Banjar, Setra dan Kahyangan Tiga yang ada di wewengkon desa Pekraman. Secara pro-aktif dalam menjaga keamanan dan ketertiban lingkungan masyarakat, menelisik kemungkinan terindikasi adanya rencana-rencana perilaku subversive yang tidak kondusif dan membahayakan masyarakat dapat juga disebut sebagai bentuk modal sosial masyarakat Bali.

Di era digitalisasi ini, saat kemajuan Artifisial Intelegent (Al) sangat pesat, para pelaku pembangunan seakan ketakutan akan ketinggalan atau digilas oleh kemajuan zaman, sehingga mengarahkan strategi pembanguannya pada penyiapan sumber daya manusia (human capital) dan pembangunan berbagai infrastruktur yang meguras modal uang (economic capital). Dalam 
hal ini, cenderung melupakan perhatian pada kualitas interaksi sosial masyarakat (social capital), dimana keberadaan modal terakhir ini adalah mengkatalis pencapaian pemerataan pembangunan. Di Provinsi Bali, perhatian pemerintah pada pembangunan kualitas interaksi sosial mesyarakat perlu diperhatikan secara proporsional. Sehingga kedepan, tidak ada ketakutan akan kemajuan teknologi, karena seberapapun kecanggihan teknologi sejatinya masih tetap pemerlukan manusia (masyarakat) untuk mengontrol pemanfaatan kemanjuan teknologi. Alih-alih, bisa saja jadi kebablasan, karena kemajuan teknologi tanpa manusia yang arif dan bijak sebagai laeder control atas kemanjuan teknologi.

Era digitalisasi akan membawa masyarakat pada situasi yang ramai dalam kesunyian. Orang dewasa, anak-anak akan cenderung lebih menyukai di tempat yang sepi (didalam kamar yang sangat privasi), dengan sebuah "smart-phone" yang canggih, tetapi merka bisa terhubung ke berbagai situs yang mereka inginkan. Dengan berbagai rogram aplikasi seperti: facebook, watsapp, instagram, games, dan aplikasi lainnya, mereka dapat mengakses berbagai situs sesuai apa yang mereka inginkan. Kenyataan ini, akan secara sistematis, lambat tapi pasti akan membawa masyarakat Bali ke pergeseran pola kehidupan, dari yang semula berpola kolektif, altruis, proaktif penuh inisiatif, menjadi individual yang apatis. Dari semula, lebih menyukai bertukar pikiran di Balai Banjar, menjadi lebih suka menyendiri, menikmati berbagai situs yang dapat diakses secara on-line melalui smart-phone yang ada digemgamannya. Kebiasaan masyarakat yang kurag kondusif ini, lambat laun akan membuat permasalahan yang serius bagi keberadaan masyarakat Bali, yaitu mengubah pola kekerabatan masyarakat yang semula hidup harmonis dalam kebersamaam, menjadi masyarakat yang indibivualistis dan apatis.

Harus ada upaya yang sitematis pula untuk mengantisipasi perubahan-perubahan perilaku masyarakai ini, baik dari pihak pemerintah maupun masyarakat itu sendiri. Upaya sistematis itu adalah dengan sengaja menstimulasi agar kualitas interaksi sosial antar individu dalam kelompok (dalam keluarga), antar kelompok dengan kelompok (dalam Banjar, istitusi pemerintah), sebagai modal sosial, yang sangat diperlukan untuk memelihara hasil pembangunan yang sudah dicapai oleh pemerintah untuk masyarakatnya. Tidak bisa dipungkuri, bahwa dewasa ini kualitas smsrt-phone yang dimiliki oleh seseorang menunjukkan prestise sosial. Sehingga para orang tua dengan sengaja memberikan benda ini kepada anakanaknya, tanpa mempertimbangkan tingkat usia dan perkembangan psikologis. Disadari atau tidak, tindakan ini adalah awal melemahnya kualitas interaksi sosial antara anak dan orang tuanya. Demikian seterusnya sampai ke tataran terbentuknya sifat individualis dan apatis bagi anak-anak. Hal yang sama, terjadi juga pada orang dewasa, yang akhirnya member warna pada kualitas interaksi antar kelompok dalam masyarakat.

\section{KESIMPULAN DAN REKOMENDASI}

Berdasarkan paparan di atas, dapat disarikan sebagai kesimpulan akan pembahasan yang telah diuraikan di atas, yaitu: 1). Kualitas interaksi sosial dalam masyarakat Bali adalah modal sosial yang kontribusinya tidak kecil dalam pembangunan manusia seutuhnya,seperti apa yang diamanatkan oleh tujuan pembangunan bangsa Indonesia. 2). Modal sosial masyarakat Bali secara hirarkis terbentuk mulai dari anutan Nilai-nilai yang ditanamkan sejak kecil, yang selanjutnya akan membentuk norma sosial yang diakui dan dipatuhi dalam kelompok. Kebiasaan mentaati norma-norna yang ada dalam kelompok masyarakat akan menumbuhkan rasa percaya-mempercayai dalam satu kelompok. Terbentuknya trust di dalam kelompok akan menyebabkan keingnan untuk salung membantu dalam saling bertukar kebaikan dalam kelompok; tingkar resiprocity yang tinggi dalam masyarakat akan menunbukan partisipasi dalan jalinan anngita masyarakat dan membentuk jaringan sosial. Kekentalan hubungan sosial masyarakat akan menumbuhkan tindakan proaktif dalam masyarakat, yaitu tidak saja memang 
berpatisipasi, tetapi proaktif mendahului melakukan tindakan yang kondusif bagi kesejarteraah dan keamanan dalam masyarakat.

Satu hal yang menjadi rekomendasi dari tulisan ini, kepada masyarakat maupun pemerintah sebagai pelaku pembangunan yaitu: hendaknya member prosi yang seimbang dalam pengalokasian dan memanfaatan modal pembangunan yaitu yang disebut sebagai economic capital, human capital, dan social capital. Karena peran ketiga jenis midal ini dalam pembangunan adalah inhern, tidak terpisahkan dan saling menentukan.

\section{REFFERENSI}

Hasbullah, Jousairi. 2006. Social Capital: Menuju Keunggulan Budaya Manusia Indinesia. Jakarta: MR-United Press Jakarta

Kasali, Rheinald. 2018. The Great Shifting. Jakarta: PT Gramedia Pustaka Utama.

Kuncoro, Mudrajad. 2012. Perencanaan Daerah, Bagaimana Membangun Ekonomi Lokal, Kota dan Kawasan. Jakarta: Salemba Empat. 